\title{
Prohormone Convertase 1 Deficiency
}

National Cancer Institute

\section{Source}

National Cancer Institute. Prohormone Convertase 1 Deficiency. NCI Thesaurus. Code C120407.

Deficiency or dysfunction of the enzyme prohormone convertase 1 associated with lossof-function mutation(s) in the PCSK1 gene. 